\title{
Effect of emplaced nZVI mass and groundwater velocity on PCE dechlorination and hydrogen evolution in water-saturated sand
}

Hye-Jin Kim ${ }^{1,2}$, Megan Leitch ${ }^{1,5}$, Bhanuphong Naknakorn ${ }^{1}$, Robert D. Tilton ${ }^{3,4,5}$, Gregory V. Lowry ${ }^{1,3,5 *}$

${ }^{1}$ Civil \& Environmental Engineering, ${ }^{3}$ Chemical Engineering, ${ }^{4}$ Biomedical Engineering, ${ }^{5}$ Center for Environmental Implications of Nanotechnology

Carnegie Mellon University, Pittsburgh, PA 15213-3890, USA.

${ }^{2}$ Water Environment Research Department, National Institute of Environmental Research,

Incheon, 404-708, Korea

*Corresponding author: G.V. Lowry (glowry@cmu.edu) 412-268-2948 (phone) 412-268-7813 (fax) 


\section{Abstract}

The effect of nZVI mass loading and groundwater velocity on the tetrachloroethylene (PCE) dechlorination rate and the hydrogen evolution rate for poly(maleic acid-co-olefin) (MW=12K) coated nZVI was examined. In batch reactors, the PCE reaction rate constant $\left(3.7 \times 10^{-4} \mathrm{~L} \mathrm{hr}^{-1} \mathrm{~m}^{-2}\right)$ and hydrogen evolution rate constant $\left(1.4\right.$ nanomol $\left.\mathrm{L} \mathrm{hr}^{-1} \mathrm{~m}^{-2}\right)$ were independent of nZVI concentration above $10 \mathrm{~g} / \mathrm{L}$, but the PCE dechlorination rate decreased and the hydrogen evolution rate increased for nZVI concentration below $10 \mathrm{~g} / \mathrm{L}$. The nonlinearity between nZVI mass loading and PCE dechlorination and $\mathrm{H}_{2}$ evolution was explained by differences in $\mathrm{pH}$ and $\mathrm{E}_{\mathrm{h}}$ at each NZVI mass loading; PCE reactivity increased when solution $\mathrm{E}_{h}$ decreased, and the $\mathrm{H}_{2}$ evolution rate increased with decreasing $\mathrm{pH}$. Thus, nZVI mass loading of $<5 \mathrm{~g} / \mathrm{L}$ yields lower reactivity with PCE and lower efficiency of $\mathrm{Fe}^{0}$ utilization than for higher nZVI mass loading. The PCE dechlorination rate increased with increasing pore-water velocity, suggesting that mass transfer limits the reaction at low porewater velocity. Overall, this work suggests that design of nZVI-based reactive barriers for groundwater treatment should consider the non-linear effects of both mass loading and flow velocity on performance and expected reactive lifetime.

Key words: Nanoiron, Environmental nanotechnology, In situ remediation, DNAPL, Groundwater treatment

\section{Introduction}

Nano-scale zero valent iron (nZVI) is a proposed remediation technology for aquifers contaminated with chlorinated organic contaminants including tetrachloroethylene (PCE), heavy metals, and oxoanions [1-8]. The ability of nZVI to decrease contaminant concentrations is situ has been demonstrated. For example, Soukupova et al. showed that the injection of a surfactant modified nZVI resulted in significant reduction of total chlorinated hydrocarbons (CHC) including tetrachloroethylene 
(PCE) [9]. Kober et al., showed that nZVI flakes could reduce PCE concentrations in situ by more than 2 orders of magnitude for over a year in a sandy aquifer [10]. Electrons from the oxidation of $\mathrm{Fe}^{0}$ are used to reduce contaminants to non-toxic products or to reduce and immobilize heavy metals in situ. The high surface to volume ratio of nZVI increases reactivity with contaminants compared to micronsized iron. For example, Zhang et al. (2009) reported that the reduction rate of 2,4,6-trinitrotoluene (TNT) on nZVI was 7.8 times higher than for conventional iron powder. This high reaction rate would allow for less extensive permeable reactive barriers (PRBs) when using nZVI compared to micronsized ZVI [11]. Another proposed advantage of nZVI over micron-sized $\mathrm{Fe}^{0}$ particles is that the small size of nZVI enables emplacement in the subsurface using injection wells or through preexisting monitoring wells after modification with anionic polyelectrolytes [9, 12]. This method of application both eliminates the high initial cost of installing of a traditional PRB and allows access to greater depths for groundwater remediation. Kocur et al. estimated that nZVI coated with carboxymethyl cellulose polymer traveled at least $1 \mathrm{~m}$ using a gravity fed system [12], suggesting the potential for creating reactive barriers in situ. There are additional challenges for the in situ application of NZVI [13]. These include the potentially limited reactive life time for NZVI [14], especially in scenarios where groundwater entering the reactive zone contains oxidants (e.g. dissolved oxygen or nitrate) that can rapidly consume the elemental iron in NZVI $[15,16]$. Groundwater chemical constituents like divalent cations and natural organic matter and can also decrease reactivity [17]. Finally, there may be site-, regional-, or country- specific regulatory hurdles to its implementation.

The reaction rate of contaminants with nZVI must be known to determine the mass of nZVI needed to create a reactive zone with sufficiently high reactivity to degrade contaminants passing through it. Unfortunately, the interaction between nZVI and contaminants is nonspecific. In addition to the contaminant of interest, the electrons from iron oxidation are also consumed from the reduction of water $\left(\mathrm{H}_{2} \mathrm{O}\right)$ or protons $\left(\mathrm{H}^{+}\right)$to hydrogen $\left(\mathrm{H}_{2}\right)$. Since water is present at a much higher concentration than contaminants and readily oxidizes nZVI, the hydrogen evolution rate is a good measure of the rate 
of consumption of $\mathrm{Fe}(0)$ and therefore reactive lifetime of the nZVI $[14,18]$. The contaminant reduction rate and the hydrogen evolution rate may be influenced by both the emplaced nZVI concentration and the velocity of the groundwater moving through the reactive zone. Emplacement of surface-modified nZVI into the targeted area will result in spatially non-uniform distribution which depends on the injection velocity, groundwater flow, physical heterogeneity in aquifers, and hydrogeochemical conditions $[5,6,19,20]$. Contaminant degradation could be easily modeled if reactivity of nZVI were proportional to mass loading and unaffected by the wide range of possible groundwater velocities, as stated by the theory below.

At low contaminant concentrations typically encountered, the rate of reaction of nZVI with contaminants is second-order and depends on the contaminant concentration, $\mathrm{C}(\mathrm{M})$ and iron reactive surface area concentration, $\rho_{\mathrm{a}}\left(\mathrm{m}^{2} \mathrm{~L}^{-1}\right)=\mathrm{a}_{\mathrm{s}} \cdot \rho_{\mathrm{m}}$ where $\rho_{\mathrm{m}}(\mathrm{g} / \mathrm{L})$ is the mass loading of the iron and $\mathrm{a}_{\mathrm{s}}\left(\mathrm{m}^{2} / \mathrm{g}\right)$ is the surface area of the iron [21, 22]. Often, this second-order surface area normalized reaction rate constant, $\mathrm{k}_{\mathrm{SA}}\left(\mathrm{Lh}^{-1} \mathrm{~m}^{-2}\right)$, is combined with the nZVI surface area concentration (assumed to be proportional to mass loading) to provide a pseudo first order reaction with respect to the contaminant concentration (eqn 1).

$$
-\frac{d[C]}{d t}=k_{S A} \cdot \rho_{a} \cdot[C]=k_{S A} \cdot a_{s} \cdot \rho_{m}[C]=k_{o b s}[C]
$$

If $\mathrm{k}_{\mathrm{SA}}$ and $\mathrm{a}_{\mathrm{s}}$ are assumed to be constant there is a linear relationship between $\rho_{\mathrm{m}}$ (nZVI mass loading) and $\mathrm{k}_{\mathrm{obs}}\left(\mathrm{h}^{-1}\right)$. This assumption would allow for scaling $\mathrm{k}_{\mathrm{obs}}$ over a wide range of $\mathrm{nZVI}$ concentration, and would be convenient for remediation system design. However, there are conflicting reports regarding the linearity of $\mathrm{k}_{\mathrm{obs}}$ with ZVI mass loading, both for micron sized iron filings [23, 24] and for uncoated, low dose nZVI [25]. The relationship between the concentration of $n Z V I$ and $k_{o b s}\left(h^{-1}\right)$ for a 
commercially available anionic polyelectrolyte-modified nZVI for the expected range of particle dosages ( $\sim 0.5$ to $20 \mathrm{~g} / \mathrm{L})$ for the field application has not been studied.

Because the reaction of $\mathrm{Fe}^{0}$ with chlorinated organics is a surface-mediated process, direct contact of contaminants with nZVI is necessary $[26,27]$. Given the high rate of reaction of contaminants with nZVI and the typically low velocity of groundwater (1 to $320 \mathrm{~cm} /$ day) [28], interfacial mass transfer of the contaminant from the bulk solution to the nZVI surface can be the limiting step for the reactivity. The mass transfer coefficient between the bulk solution and the nZVI surface is directly proportional to the diffusion coefficient of contaminants and inversely proportional to the thickness of boundary layer on the nZVI surface. Low seepage velocity increases the thickness of the boundary layer [29]. The buildup of $\mathrm{H}_{2}$ gas bubbles on the nZVI surface may also affect PCE diffusion to the nZVI surface. Stability of these bubbles on the nZVI surface may be a function of the water velocity flowing past the particles. nZVI reactivity studies with contaminants have typically used batch reactors which do not account for the effect of flow on contaminant reactivity [14, 30-32]. Determination of the rate of PCE dechlorination by nZVI, the byproducts formed, and hydrogen generated under flow conditions are needed to design barrier systems employing nZVI.

The objectives of this study are to determine the PCE dechlorination rate and byproducts formed, and the $\mathrm{H}_{2}$ evolution rate with respect to nZVI mass loading and groundwater velocity. The relationship between the PCE or hydrogen reaction rate and the mass loading of nZVI was determined under a range of field application-relevant nZVI concentrations in batch reactors. The effect of groundwater velocity on PCE reactivity was determined in columns packed with nZVI and sand over a range of seepage velocities typical for groundwater.

\section{Materials and Methods}

\subsection{Chemicals.}


PCE (99.5\%) was from Aldrich. Sodium bicarbonate (99 wt. \%) was from Fisher Scientific. Acetylene (1000 ppmv and 100 ppmv), ethylene (1000 ppmv and 100 ppmv), ethane (1000 ppmv and 100 ppmv), vinyl chloride (VC) (10 ppmv) and hydrogen (1.08 volume \%) standards were from Matheson Tri Gas. Ultra high purity argon, ultra high purity helium, hydrogen (5.18 volume \%), air and $\mathrm{N}_{2}$ were from Butler Gas Products (Pittsburgh, PA). Anoxic ferrous iron stock solutions were prepared from $\mathrm{FeCl}_{2} \cdot 4 \mathrm{H}_{2} \mathrm{O}(>99 \%$, Acros Organics).

\section{$2.2 \mathrm{Fe}^{0} / \mathrm{Fe}_{3} \mathrm{O}_{4}$ Nanoparticles.}

The nZVI used in this study was MRNIP2, reactive nano-iron particles modified with poly (maleic acid-co-olefin) with an average molecular weight of $12,000 \mathrm{~g} / \mathrm{mol}$ and was supplied by Toda Kogyo Corp. (Onoda, Japan). MRNIP2 is composed of an $\mathrm{Fe}^{0}$ core and $\mathrm{Fe}_{3} \mathrm{O}_{4}$ shell with primary particle sizes from 20 to $60 \mathrm{~nm}$. The isoelectric point of bare material was $\mathrm{pH}_{\mathrm{iep}} 6.3$ [33]. The physical chemical properties of Toda Kogyo nZVI particles have been previously reported [14, 31, 34-36]. nZVI handling

and stock solution preparation are discussed in the Supplementary Information. The $\mathrm{Fe}^{0}$ content of particles (47 wt. \%) was determined from acid digestion and measurement of the $\mathrm{H}_{2}$ formed just prior to when the batch and column experiments were conducted [31]. The nZVI used to study the effect of added $\mathrm{Fe}(\mathrm{II})$ and $\mathrm{pH}$ on PCE reactivity was from a different MRNIP2 batch and had $\mathrm{Fe}^{0}$ content of 36 wt. \%. The $\mathrm{N}_{2}$-BET specific surface area of the $\mathrm{nZVI}\left(\mathrm{a}_{\mathrm{s}}\right)$ was $\sim 15 \mathrm{~m}^{2} / \mathrm{g}[19]$.

\subsection{Porous Matrix.}

Silica sand (Unimin \#50) with a $300 \mu \mathrm{m}$ average diameter $\left(\mathrm{d}_{50}\right)$ and a specific gravity of $2.67 \mathrm{~g} / \mathrm{cm}^{3}$ was used as a model porous matrix (Unimin Corp. (Emmett, Idaho)). The grain size distribution and other physical properties are provided in the Supplementary Information (Figure A1).

\subsection{Effect of nZVI Mass Loading on PCE Reactivity and $\mathrm{H}_{2}$ Evolution in Batch Reactors.}


The PCE dechlorination rate, byproducts formed and hydrogen evolution rate were measured to determine the effect of nZVI mass loading ( $1 \mathrm{~g} / \mathrm{L}, 2 \mathrm{~g} / \mathrm{L}, 5 \mathrm{~g} / \mathrm{L}, 10 \mathrm{~g} / \mathrm{L} 15 \mathrm{~g} / \mathrm{L}$ or $20 \mathrm{~g} / \mathrm{L})$. Reactors with $70 \mathrm{~mL}$ serum bottles containing $40 \mathrm{~mL}$ head space, $30 \mathrm{~mL}$ of liquid and a mininert cap were prepared in an anaerobic glove box (Argon filled). nZVI reactors were buffered with $5 \mathrm{mM} \mathrm{NaHCO}$ in $\mathrm{N}_{2^{-}}$ purged water to minimize oxidation of particles due to dissolved oxygen. Bicarbonate was chosen as background ionic species for the experiments for environmental relevance. However, it is acknowledged that some passivation could result from ferrous carbonate precipitates [37-39]. An aliquot of $1 \mathrm{~mL}$ PCE-saturated water $(0.87 \mathrm{mM})$ was added to provide an initial PCE concentration in the water of $29 \mu \mathrm{M}$. Experiments were performed in duplicate. The reactors were rotated end-over-end at $30 \mathrm{rpm}$ at $23 \pm 2{ }^{\circ} \mathrm{C}$. In control experiments without nZVI, PCE losses by other mechanisms (photo degradation, adsorption and leakage) were negligible. Mass transfer resistance at the vapor/liquid interface was not considered because these phases are assumed to be in equilibrium. At specified time points, a $100 \mu \mathrm{L}$ headspace sample was withdrawn from the reactors and was analyzed for PCE and its byproducts using GC/FID. A second $100 \mu \mathrm{L}$ headspace sample was removed and analyzed for $\mathrm{H}_{2}$ using GC/TCD. Details of analysis of PCE, byproducts and hydrogen, examples of data collected to determine the dechlorination rate constant (Figure A2) and observed PCE dechlorination pathway (Figure A3) are provided in the Supplementary Information. The $\mathrm{pH}$ and oxidation reduction potential $\left(E_{h}\right)$ were measured in an anaerobic chamber at the end of each experiment $(t=162 \mathrm{~h})$.

\subsection{Determination of Factors That May Affect Reactivity under Various nZVI Loadings.}

The $\mathrm{pH}$ and $\mathrm{E}_{\mathrm{h}}$ in the batch reactors changed as a function of nZVI mass loading. To determine the reason for the non-linear increase in reactivity vs. nZVI loading, a second set of batch reactors were created, all containing $2 \mathrm{~g} / \mathrm{L}$ nZVI, on which the effect of adsorbed Fe(II), pH, and $\mathrm{E}_{\mathrm{h}}$ on PCE reactivity and $\mathrm{H}_{2}$ evolution were measured. The concentration of $\mathrm{Fe}(\mathrm{II})$ was varied from 0 to $5 \mathrm{mM}(0$, 
$0.5,1,2,5 \mathrm{mM}$ ) by adding $\mathrm{FeCl}_{2}(\mathrm{~s})$. $\mathrm{pH}$ was adjusted by adding $10 \mathrm{mM} \mathrm{NaOH}$ or $10 \mathrm{mM} \mathrm{HCl}$ to the reactors such that the $2 \mathrm{~g} / \mathrm{L} \mathrm{nZVI}$ slurry would react at a designated $\mathrm{pH}$.

The $\mathrm{pH}, \mathrm{E}_{\mathrm{h}}$ and the concentration of dissolved $\mathrm{Fe}(\mathrm{II})$ in the solution were measured after 2 days of equilibration on the end over end rotator (prior to adding PCE), and again at the end of the PCE degradation reaction $(\mathrm{t}=162 \mathrm{~h})$. See the Supplementary Information for a description of the ferrozine method to quantify the concentration of dissolved $\mathrm{Fe}(\mathrm{II})$ under different $\mathrm{pH}$ conditions [40]. For all cases, the $\mathrm{pH}$ increased $\leq 0.3$ units and $\mathrm{E}_{\mathrm{h}}$ became $\sim 100 \mathrm{mV}$ less negative (more oxidizing) after the one week reaction time.

\subsection{Effect of Seepage Velocity on the PCE Dechlorination.}

The influence of seepage velocity on the PCE dechlorination rate constant $\left(\mathrm{k}_{\mathrm{obs}}\right)$ was determined in flow-through column reactors. Four different velocities were used $(7,14,53$ and $113 \mathrm{~cm} /$ day) in an up flow configuration. A glass column $(31 \mathrm{~cm} \times 2.68 \mathrm{~cm}$ ID) with glass frits at the both ends was packed with a homogeneous mixture of sand $(300 \mu \mathrm{m})$ and enough $\mathrm{nZVI}$ to provide $10 \mathrm{~g} / \mathrm{L}$ of MRNIP2 in the pore water which corresponds to $0.76 \mathrm{wt} \%$ iron in the sand packing. The porosity of the sand column without nZVI was 0.43 as determined from a tracer test using $\mathrm{D}_{2} \mathrm{O}$ [41]. Further column preparation methods, including efforts to discourage premature nZVI oxidation, buffering, and column pressurization to simulate subsurface depth, are reported in Supplementary Information.

The value of $\mathrm{k}_{\mathrm{obs}}$ measured in the reactors was calculated assuming plug flow and eqn 2 where,

$$
k_{\text {obs }}=-\frac{\ln \frac{C}{C_{0}}}{t}
$$

$\mathrm{C}=\mathrm{PCE}$ concentration along the $\mathrm{Fe}^{0}$ packed column (effluent) $(\mathrm{mg} / \mathrm{L}), \mathrm{C}_{0}=$ initial $\mathrm{PCE}$ concentration (influent) $(\mathrm{mg} / \mathrm{L}), \mathrm{k}_{\mathrm{obs}}=$ first order dechlorination rate constant $\left(\mathrm{h}^{-1}\right)$, and $\mathrm{t}=$ retention time in the column 
(h). Column experiment procedures and methods for measurement of PCE are discussed in Supplementary Information.

\section{Results and Discussion}

\subsection{Effect of nZVI Mass Loading on PCE Reactivity and Hydrogen Evolution in Batch Reactors.}

The kinetics of PCE dechlorination by MRNIP2 were adequately fit assuming the formation of acetylene as a reactive intermediate (Figure A3). Formation of acetylene as a reaction intermediate was also observed for TCE dechlorination by an uncoated form of the same nZVI as used here [42] (Figure A3). The primary reaction products were ethene and ethane. Chlorinated by-products such as chloroethene, 1,2-dichloroethylene and 1,1-dichloroethylene were not detected during the reaction. Acetylene was a reactive intermediate that ultimately transformed to ethene and ethane. The mole ratio between ethene and ethane for PCE dechlorination was 3.6 and was independent of nZVI concentration over the concentration range evaluated which can be a particle specific property. This ratio appears to be relatively consistent for RNIP and modified RNIP for both PCE and TCE. Liu and Lowry reported an ethane/ethane molar ratio of 3.6 for TCE dechlorination by unmodified RNIP reacted with TCE at $4.4 \mathrm{mg} / \mathrm{L}\left(1.9 \mathrm{~g} / \mathrm{L}\right.$ of $\left.\mathrm{Fe}^{0}\right)$ [14]. Kopinke et al., 2016 found that the ethane to ethane product ratio was 4.3 \pm 0.2 by using RNIP alone, and $4.0 \pm 0.2$ by using RNIP with AC [43]. Similarly, Gao et al., 2015 found and ethane to ethane ratio of 4 for TCE dechlorination by milled zerovalent iron [44]. However, the choice of support can affect this ratio. They found that this ratio varied from 3.25 to 7 for an $\mathrm{Fe}-\mathrm{C}$ composite and Fe/carbon mixture, respectively [44]. It should be noted that the type of NZVI can also greatly affect this ratio. Nanoiron particles synthesized from sodium borohydride reduction of ferrous iron (Fe/B) transformed TCE primarily to ethane (80\%) and C3-C6 coupling products (20\%) [42]. The same suite of reaction products was also observed from bimetallic $(\mathrm{Pd} / \mathrm{Fe}, \mathrm{Ni} / \mathrm{Fe})$ iron $[45,46]$ and 
$\mathrm{Pd} / \mathrm{Fe}$ bimetallic nano particles-catalyzed dechlorination [47]. In all cases, the carbon mass balance for all PCE degradation experiment was $>90 \%$.

The $\mathrm{k}_{\mathrm{SA}}$ values calculated for the MRNIP2 concentrations from $1 \mathrm{~g} / \mathrm{L}$ to $20 \mathrm{~g} / \mathrm{L}$ are shown in Figure 1a. Additional details are provided in Table A1 in the Supplementary Information. The kSA ranged from 2.0 to $3.8 \times 10^{-4} \mathrm{Lh}^{-1} \mathrm{~m}^{-2}$, four to eight-fold lower than the $\mathrm{k}_{\mathrm{SA}}$ of PCE measured using uncoated nZVI $\left(1.57 \times 10^{-3} \mathrm{Lh}^{-1} \mathrm{~m}^{-2}\right.$ at $10 \mathrm{~g} / \mathrm{L}$ mass loading [48]). This difference is attributed to the effect of the adsorbed polyelectrolyte and is consistent with previous studies, where coated nZVI had decreased reactivity with TCE from 3.5 to 20 times compared with bare nZVI depending on the type of polymeric coating used $[6,19]$. Note that the lower reactivity of NZVI due to sorption of CMC is expected for the post-synthesis coating of the NZVI prepared by gas-phase reduction of iron oxides with $\mathrm{H}_{2}$. However, adding CMC (carboxyl methyl cellulose) into an iron precursor solution presynthesis enhanced the reactivity of NZVI produced by borohydride reduction of dissolved iron salts by 17 times compared to the absence of CMC. This is because in these cases the presence of CMC leads to smaller and more stable NZVI particles compared to the absence of CMC [49-51].

The $\mathrm{k}_{\mathrm{SA}}\left(\mathrm{Lh}^{-1} \mathrm{~m}^{-2}\right)$ is expected to be constant if the reaction is first order with respect to iron mass loading. However, the relationship between nZVI concentration and reactivity was not first order over the entire concentration range tested. A first order relationship between nZVI dosage and PCE reactivity was valid only for iron mass loadings above $10 \mathrm{~g} / \mathrm{L}$. Below $10 \mathrm{~g} / \mathrm{L}, \mathrm{k}_{\mathrm{SA}}$ decreases as the mass loading decreases (Figure 1a).

A nonlinear relationship between $\mathrm{k}_{\mathrm{SA}}$ and iron mass loading has been reported for micron sized granular iron filings $[23-25,52,53]$. However, these prior reports typically show the opposite trend, i.e. a first order dependence on iron mass loading at low mass loadings followed by a decrease in $\mathrm{k}_{\mathrm{SA}}$ at high mass loadings. Arnold and Roberts [52] attributed the non-linear effect of iron concentration on PCE reactivity to insufficient mixing at high iron dosage (above $3.1 \mathrm{~g} / \mathrm{L}$ ). Cwiertny and Roberts [23] 
hypothesized that the formation of a thicker Fe-oxide layer above $3.2 \mathrm{~g} / \mathrm{L}$ passivated the reaction of granular iron due to the higher $\mathrm{pH}$ at high mass loading. For both cases, the nonlinearity occurred at relatively low iron concentration $(\sim 3 \mathrm{~g} / \mathrm{L})$.

Studies investigating the effect of nZVI concentration on reactivity have been reported. However, all were determined using nZVI made from reducing $\mathrm{Fe}^{2+}$ with sodium borohydride. Choe et al [25] and Song and Carraway $[54,55]$ reported that nZVI reactivity was first order with respect to nZVI mass loading, though the range studied was only from $0.1 \mathrm{~g} / \mathrm{L}$ to $0.5 \mathrm{~g} / \mathrm{L}$. The relatively low reactivity of MRNIP2 compared to bare nZVI allows for testing higher nZVI mass loadings that are more typical for in situ remediation (1 to $20 \mathrm{~g} / \mathrm{L}$ ). Because of the high surface area of nZVI compared to micron-sized ZVI and the high mass loading allowed by use of MRNIP2, the iron surface area per volume of solution in this study is 40-1000 times greater than the previous three studies. This has important implications due to the resulting decrease in $\mathrm{E}_{\mathrm{h}}$ and increase in $\mathrm{pH}$ [54] in reactors as discussed later. nZVI-driven generation of $\mathrm{H}_{2}$ gas as well as $\mathrm{Fe}^{2+}$ and $\mathrm{Fe}^{3+}$ species will affect system redox potential, however it was hypothesized that variations in surface-coated nZVI reactivity were controlled chiefly by $\mathrm{E}_{\mathrm{h}}$ or $\mathrm{pH}$, not by appearance of the new species.

The reactor $\mathrm{H}_{2}$ concentration increased linearly with time for a given nZVI mass loading. This is in contrast to previous reports that $\mathrm{H}_{2}$ evolution is pseudo-first-order with respect to the mass of $\mathrm{Fe}^{0}$ in the particles [14]. The difference between these studies is that $\mathrm{H}_{2}$ evolution was measured for 20 to 30 hours whereas Liu and Lowry (2006) measured $\mathrm{H}_{2}$ evolution over a 20 to 30 day period. Thus, the $\mathrm{H}_{2}$ evolution rates reported here represent initial rates where it is difficult to distinguish between zero order and first order with respect to $\mathrm{Fe}^{0}$ mass in the particles. Regardless, the initial $\mathrm{H}_{2}$ evolution rate depended on the nZVI mass loading (Figure 1b). The surface area normalized hydrogen evolution rate was independent of nZVI mass loading above $10 \mathrm{~g} / \mathrm{L}$, but increased 3-fold for nZVI concentration below $5 \mathrm{~g} / \mathrm{L}$. This trend in reactivity at low particle loading is opposite to the trend observed for the PCE dechlorination. 


\subsection{Determination of Factors Which May Affect Reactivity under Various nZVI Loadings.}

To determine why nZVI loading affected the PCE degradation rate and $\mathrm{H}_{2}$ evolution rate differently, the $\mathrm{pH}$ and $\mathrm{E}_{\mathrm{h}}$ of the solutions in the reactors were measured. $\mathrm{pH}$ can affect both the PCE dechlorination (eqn 4) and the $\mathrm{H}_{2}$ evolution (eqn 5). Although $5 \mathrm{mM}$ sodium bicarbonate was used in an attempt to control pH, nZVI corrosion produced hydroxide ions (eqn 5) and exceeded the buffer capacity of the solution for some nZVI loadings. The final $\mathrm{pH}$ in the reactors ranged from $\mathrm{pH} 9.3$ to 10.9 (Figure 1c). The $\mathrm{E}_{\mathrm{h}}$ in the system also depended on the $\mathrm{nZVI}$ loading and ranged from $-380 \mathrm{mV}$ at the lowest nZVI loading $(1 \mathrm{~g} / \mathrm{L})$ to $-480 \mathrm{mV}$ for nZVI loading $>10 \mathrm{~g} / \mathrm{L}$ (Figure 1d). The trends observed for $\mathrm{pH}$ and $\mathrm{E}_{\mathrm{h}}$ vs. nZVI loading were similar to the trends observed for PCE reactivity and $\mathrm{H}_{2}$ evolution, i.e. changing most significantly below $10 \mathrm{~g} / \mathrm{L}$ nZVI. Generally, increasing $\mathrm{pH}$ and decreasing $E_{h}$ enhanced the dechlorination rate and decreased the hydrogen evolution rate. However, in all cases both $\mathrm{E}_{\mathrm{h}}$ and $\mathrm{pH}$ were changing during the reaction so it was difficult to determine with certainty the factor responsible for the change in reactivity.

$$
\begin{aligned}
& \mathrm{Fe}^{0} \rightarrow \mathrm{Fe}^{2+}+2 \mathrm{e}^{-} \\
& \mathrm{PCE}+\mathrm{n} \cdot \mathrm{H}^{+}+\mathrm{m} \cdot \mathrm{e}^{-} \rightarrow \text { products }+4 \mathrm{Cl}^{-} \\
& 2 \mathrm{H}_{2} \mathrm{O}+4 \mathrm{e}^{-} \rightarrow \mathrm{H}_{2} \uparrow+2 \mathrm{OH}^{-}
\end{aligned}
$$

In an attempt to distinguish the effect of $\mathrm{pH}$ from other bulk effects including $\mathrm{E}_{\mathrm{h}}$, another set of reactors was prepared with a fixed nZVI concentration $(2 \mathrm{~g} / \mathrm{L})$ but with a range of $\mathrm{pH}$ values. The results are presented in Figure 2. Controlling $\mathrm{pH}$ at a constant nZVI mass loading (filled circles) displayed the same $\mathrm{pH}$ dependency on the hydrogen evolution rate as the results with various nZVI concentrations (open circles). A linear relationship between $\mathrm{pH}$ and $\mathrm{H}_{2}$ evolution rate was observed over the $\mathrm{pH}$ range 7 to 11 which covers the $\mathrm{pH}$ range of most groundwater after the emplacement of 
nZVI. Therefore, the nonlinear relationship between $\mathrm{H}_{2}$ evolution rate and nZVI mass loading (Figure 1b) is attributed to the increased $\mathrm{pH}$ at higher mass loading which limits the supply of protons for reduction by $\mathrm{Fe}^{0}$. It should be noted the dependency of hydrogen evolution rate on $\mathrm{pH}$ for MRNIP2 (slope $=0.2)$, is weaker than the dependency for bare nZVI (slope $=\sim 1$ ) [14]. Conversely, hydrogen evolution did not show a clear relationship with $\mathrm{E}_{\mathrm{h}}$ in reactors containing $2 \mathrm{~g} / \mathrm{L}$ (Figure A4). Therefore, it appears that changes in $\mathrm{pH}$ rather than $\mathrm{E}_{\mathrm{h}}$ control the reactivity of $\mathrm{nZVI}$ with protons to form $\mathrm{H}_{2}$.

Increasing nZVI mass loading increased $\mathrm{pH}$ but decreased $\mathrm{E}_{\mathrm{h}}$ (Figure 1d) so it is unclear whether the PCE dechlorination rate was controlled by $\mathrm{E}_{\mathrm{h}}, \mathrm{pH}$, or both. Figure 3 shows measured $\mathrm{k}_{\mathrm{SA}}$ vs. $\mathrm{pH}$ for the set of reactors with various $\mathrm{nZVI}$ concentrations and for the reactors at constant $2 \mathrm{~g} / \mathrm{L}$ that were adjusted to provide a range of reactor $\mathrm{pH}$. In both cases, PCE reactivity increased as $\mathrm{pH}$ increased. However, controlling $\mathrm{pH}$ at $2 \mathrm{~g} / \mathrm{L} \mathrm{nZVI}$ showed four times less effect than when mass loading also increased. This result suggests that the increase in the PCE dechlorination rate is only partially due to the elevated $\mathrm{pH}$. Another possibility is increased nZVI mass loading decreases $\mathrm{E}_{\mathrm{h}}$ and provides driving force for PCE dechlorination [56, 57]. Measured PCE dechlorination rates from all of the $\mathrm{nZVI}$ concentrations and $\mathrm{pH}$ conditions with respect to $\mathrm{E}_{\mathrm{h}}$ are shown in Figure 4 . Generally, the variation in the measured $\mathrm{k}_{\mathrm{SA}}$ is explained by variation in measured $\mathrm{E}_{\mathrm{h}}$. Overall, PCE dechlorination correlated better with $\mathrm{E}_{\mathrm{h}}$ rather than $\mathrm{pH}$ for both batches of particles evaluated, i.e. lower and higher percentage $\mathrm{Fe}^{0}$ content.

Two other possible explanations for nonlinearity of $\mathrm{k}_{\mathrm{obs}}$ with nZVI mass loading are, 1) greater reactivity of adsorbed $\mathrm{Fe}(\mathrm{II})$ on the $\mathrm{nZVI}$ at higher $\mathrm{pH}$ [58-68], or 2) inhibition of PCE dechlorination due to competitive adsorption of acetylene, the reaction intermediate [69]. This research showed no effect on reactivity by adsorbed $\mathrm{Fe}(\mathrm{II})$ (Figure A5), however acetylene accumulation may have contributed to nonlinearity of $\mathrm{k}_{\mathrm{obs}}$. At low nZVI mass loading $(<5 \mathrm{~g} / \mathrm{L})$, the acetylene transformation rate constant $\left(\mathrm{k} 2+\mathrm{k} 3=\mathrm{k}_{\mathrm{ACY}-\mathrm{SA}}\right)$ was higher than the PCE transformation rate ( $\left.\mathrm{k}_{\mathrm{PCE}-\mathrm{SA}}\right)$, i.e. $\mathrm{k}_{\mathrm{ACY}-\mathrm{SA} /}$ $\mathrm{k}_{\mathrm{PCE}-\mathrm{SA}}>1$ (Table A1, Figure A6), resulting in less acetylene accumulation in the reactors at low nZVI 
loading compared to high nZVI loading. Therefore, an inhibition of PCE dechlorination at lower nZVI concentrations due to the buildup of acetylene is possible.

\subsection{PCE Reactivity under Flow Conditions.}

Column reactivity studies were performed at different velocities to determine the effect of seepage velocity on PCE reactivity by nZVI emplaced in a water-saturated sand column. Figure A7 and A8 show typical breakthrough curves for PCE in the column packed with nZVI and sand to provide an nZVI concentration of $10 \mathrm{~g} / \mathrm{L}$ in the pore water. The calculated PCE dechlorination rate constant $\left(\mathrm{k}_{\mathrm{obs}} / \rho_{\mathrm{a}}=\mathrm{k}_{\mathrm{SA}}\right)$ determined under the range of seepage velocity are shown in Figure 5 . Two sets of data are plotted on Figure 5 because during the time the column experiments were conducted, there was a change in the color at the front end of the column from black to greenish brown which is presumed to be caused by the oxidation of nZVI. The front of discoloration in the column moved uniformly through the bed over the course of the experiment, accounting for approximately $60 \%$ of the column length by the end of the experiment. Given this change in color, it was difficult to know with certainty whether changes in reactivity were due to changes in velocity or due to oxidation and deactivation of the nZVI. Thus, we bounded the effects by calculating $\mathrm{k}_{\mathrm{SA}}$ using two methods; one assuming complete oxidation of the iron in the column where the line of discoloration was, and a second assuming that the reactivity of nZVI remained unchanged despite the color change. Increasing the velocity from $7 \mathrm{~cm} /$ day to 113 $\mathrm{cm} /$ day increased the PCE reaction rate 2.8 times. When the reacted zone was not considered (i.e. assuming that total length of the column remains reactive despite the discoloration of the nZVI), the PCE dechlorination rate increased 4.7 times when the velocity increased under the range tested. In both cases, $\mathrm{k}_{\mathrm{obs}}$ increased as the flow velocity increased, indicating that the PCE reaction rate was indeed mass transfer limited. There are several reasons for mass transfer limitations in column studies employing reactive media, e.g. diffusion to the NZVI surface, the rate of desorption of PCE from non- 
reactive (sand) sites, or changes in the medium pore structure with changes in flow [70, 71]. However, the exact nature of these limitations could not be distinguished conclusively in the present study. Another possible explanation for this mass transfer limitation, specific to reactive NZVI, is the presence of a $\mathrm{H}_{2}$ gas layer formed at the nZVI surface or that accumulates in the pore space at low flow rates but does not at the higher flow rates tested. The generation of $\mathrm{H}_{2}$ from emplaced nZVI has been reported [72]. We speculate that this gas layer may inhibit mass transfer of PCE or water (needed for the reaction) to the nZVI surface or make portions of the nZVI inaccessible to flow thereby decreasing the observed reactivity. However, outside of empirical observations of gas bubbles formed on nZVI is quiescent batch reactors, there was no direct evidence of this gas layer forming on nZVI in the column.

In addition, PCE dechlorination rates measured in the column for a seepage velocity $>14$ $\mathrm{cm} /$ day were faster than the rates determined from batch experiments. At $113.5 \mathrm{~cm} / \mathrm{day}$, the dechlorination rate was 3 times higher than the batch dechlorination rate using the same loading of nZVI. The reason for the higher reactivity under flow conditions is not clear, but this might be related to the formation of more reactive species under the flow condition such as green rust [73], or potentially to mass transfer limitations present in the batch reactors [74]. Characterization of the nZVI that was reacted with bicarbonate and dissolved PCE could confirm this hypothesis but was not included in this study.

\section{Implications for Field Application of nZVI.}

Determination of in situ nZVI reactivity under flow conditions is needed for remediation design, e.g. the required site-specific nZVI barrier thickness to achieve a specific treatment goal. Using the reactivity data from this study and assuming plug flow, the required barrier width (W) for a specific degradation goal can be estimated using eqn 9 [75]. 


$$
W=-\frac{u}{k_{o b s}} \ln \frac{C_{s s}}{C_{i n}}
$$

Column reactivity data for various flow velocities and $\mathrm{nZVI}$ at $10 \mathrm{~g} / \mathrm{L}$ was used to estimate design barrier width (W) required to achieve between $90 \%$ and $99.99 \%$ removal of PCE (Figure 6). In general, the lower groundwater velocity requires a smaller barrier thickness, however, the required barrier thickness is not linear with porewater velocity due to the decrease in the measured reaction rate at lower seepage velocity. This analysis suggests that at low velocity (typical of most groundwater) only a small barrier thickness $(<1 \mathrm{~m})$ is required to achieve fairly significant reductions in PCE concentrations. This is consistent with field observations where significant decreases in contaminant concentration are observed after nZVI injection despite the fact that the nZVI is not well distributed and short barrier thicknesses are likely achieved [76]. The $1 \mathrm{~m}$ transport distance is also consistent with the distances observed for nZVI emplaced in the field [12].

The results from this study suggest remediation strategies using low nZVI concentration $(<5$ g/L) will be less efficient than higher concentrations. At low nZVI concentration, the PCE dechlorination rate decreased while the reaction with water (hydrogen formation) increased. The reaction with water does not directly result in PCE degradation, thereby increasing the amount of nZVI needed per mass of PCE degraded. Under the highest velocity condition tested in this study $(113 \mathrm{~cm} / \mathrm{d})$ and $\mathrm{nZVI}$ at $10 \mathrm{~g} / \mathrm{L}$, less than $4 \mathrm{~m}$ of reactive zone is required to reduce PCE by $99 \%$ removal.

It is important to note that there are several assumptions made in these simple engineering calculations for nZVI barrier design. First is the assumption of a homogeneous aquifer with a uniform groundwater flow. Second, a uniform distribution of nZVI in the porous medium assumed. Neither of these conditions is likely to be met for a scenario with injected NZVI. The presence of preferential flow paths and areas devoid of emplaced NZVI will affect the overall performance. These calculations for barrier design also assume only abiotic degradation of the contaminant. While this may be true 
shortly after nZVI emplacement, ultimately biodegradation resulting from the lowered redox potential and the availability of electron donor $\left(\mathrm{H}_{2}\right)$ will likely be an important degradation mechanism [77-80]. Precisely designed bioaugmentation (e.g. controlled $\mathrm{pH}$, nutrients, and organisms) with NZVI may decrease the reliance on the ephemeral abiotic reactions afforded by nZVI. It may also increase the reaction zone and rate of reaction to yield better performance.

\section{Conclusions.}

The effect of nZVI mass loading and flow velocity on the rate and efficiency of the reduction of PCE in water by a polymer-modified nZVI was evaluated in batch and flow through systems. The PCE dechlorination rate was first order with respect to nZVI loading for nZVI concentrations greater than 10 $\mathrm{g} / \mathrm{L}$. However, the reaction rate with PCE decreased non-linearly at nZVI loadings below $10 \mathrm{~g} / \mathrm{L}$. The decrease in $\mathrm{k}_{\mathrm{sa}}$ for PCE dechlorination at lower nZVI loadings is a result of a higher $\mathrm{E}_{\mathrm{h}}$ at lower nZVI loadings compared to the higher nZVI loadings. Conversely, the $\mathrm{k}_{\mathrm{sa}}$ for $\mathrm{H}_{2}$ evolution was higher at lower nZVI loadings than for higher nZVI loadings. The lower $\mathrm{k}_{\mathrm{sa}}$ for $\mathrm{H}_{2}$ at higher $\mathrm{nZVI}$ loadings was a result of the higher $\mathrm{pH}$ obtained at the higher nZVI loadings. The $\mathrm{k}_{\mathrm{sa}}$ for PCE dechlorination increased with increasing flow velocity, indicating that the reaction was mass transfer limited. Reasons for the observed mass transfer limitation could not be determined conclusively. However, the effect of flow velocity on the $\mathrm{k}_{\mathrm{sa}}$ for PCE dechlorination was only a factor of $\sim 3$ over the velocity range from 7

$\mathrm{cm} / \mathrm{d}$ to $113 \mathrm{~cm} / \mathrm{d}$. Overall, this work suggests that design of nZVI-based reactive barriers for groundwater treatment will need to consider the non-linear effects of both mass loading and flow velocity on performance and expected reactive lifetime.

\section{Acknowledgements}


This research was funded in part by the U.S. EPA (R833326), the NSF (BES-068646 and EF-0830093), the Department of Defense through the Strategic Environmental Research and Development Program (W912HQ-06-C-0038).

\section{Appendix A. Supplementary Information}

Batch and column experiment method details, PCE dechlorination rate constants, grain size distribution of sand, PCE dechlorination and major product formation, reaction pathway for PCE and intermediates, hydrogen evolution vs. $\mathrm{E}_{\mathrm{h}}$, PCE dechlorination vs. added Fe(II), acetylene transformation relative to acetylene formation vs. nZVI concentration, examples of PCE dechlorination in the column.

\section{Literature Cited}

[1] R.A. Crane, T.B. Scott, Nanoscale zero-valent iron: Future prospects for an emerging water treatment technology, Journal of Hazardous Materials, 211 (2012) 112-125.

[2] F.L. Fu, D.D. Dionysiou, H. Liu, The use of zero-valent iron for groundwater remediation and wastewater treatment: A review, Journal of Hazardous Materials, 267 (2014) 194-205.

[3] X.Q. Li, D.W. Elliott, W.X. Zhang, Zero-valent iron nanoparticles for abatement of environmental pollutants: Materials and engineering aspects, Critical Reviews in Solid State and Materials Sciences, 31 (2006) 111-122.

[4] D. O'Carroll, B. Sleep, M. Krol, H. Boparai, C. Kocur, Nanoscale zero valent iron and bimetallic particles for contaminated site remediation, Advances in Water Resources, 51 (2013) 104-122.

[5] T. Phenrat, H.-J. Kim, T. Fagerlund, T. Illangasekare, R.D. Tilton, G.V. Lowry, Particle Size

Distribution, Concentration, and Magnetic Attraction Affect Transport of Polymer-Modified $\mathrm{Fe}^{0}$ Nanoparticles in Sand Columns, Environmental Science \& Technology, 43 (2009) 5079-5085. 
[6] N. Saleh, K. Sirk, Y.Q. Liu, T. Phenrat, B. Dufour, K. Matyjaszewski, R.D. Tilton, G.V. Lowry, Surface modifications enhance nanoiron transport and NAPL targeting in saturated porous media, Environmental Engineering Science, 24 (2007) 45-57.

[7] T. Tosco, M.P. Papini, C.C. Viggi, R. Sethi, Nanoscale zerovalent iron particles for groundwater remediation: a review, Journal of Cleaner Production, 77 (2014) 10-21.

[8] W.L. Yan, H.L. Lien, B.E. Koel, W.X. Zhang, Iron nanoparticles for environmental clean-up: recent developments and future outlook, Environmental Science-Processes \& Impacts, 15 (2013) 63-77. [9] J. Soukupova, R. Zboril, I. Medrik, J. Filip, K. Safarova, R. Ledl, M. Mashlan, J. Nosek, M. Cernik, Highly concentrated, reactive and stable dispersion of zero-valent iron nanoparticles: Direct surface modification and site application, Chemical Engineering Journal, 262 (2015) 813-822.

[10] R. Kolber, H. Hollert, G. Hornbruch, M. Jekel, A. Kamptner, N. Klaas, H. Maes, K.M. Mangold, E. Martac, A. Matheis, H. Paar, A. SchÃaffer, H. Schell, A. Schiwy, K.R. Schmidt, T.J. Strutz, S. Thummler, A. Tiehm, J. Braun, Nanoscale zero-valent iron flakes for groundwater treatment, Environmental Earth Sciences, 72 (2014) 3339-3352.

[11] X. Zhang, Y.-m. Lin, Z.-1. Chen, 2,4,6-Trinitrotoluene reduction kinetics in aqueous solution using nanoscale zero-valent iron, Journal of Hazardous Materials, 165 (2009) 923-927.

[12] C.M. Kocur, A.I. Chowdhury, N. Sakulchaicharoen, H.K. Boparai, K.P. Weber, P. Sharma, M.M. Krol, L. Austrins, C. Peace, B.E. Sleep, D.M. Oâ€ ${ }^{\text {TM} C a r r o l l, ~ C h a r a c t e r i z a t i o n ~ o f ~ n Z V I ~ M o b i l i t y ~ i n ~ a ~}$ Field Scale Test, Environmental Science \& Technology, 48 (2014) 2862-2869.

[13] C.M. Kocur, A.I. Chowdhury, N. Sakulchaicharoen, H.K. Boparai, K.P. Weber, P. Sharma, M.M. Krol, L. Austrins, C. Peace, B.E. Sleep, Characterization of nZVI mobility in a field scale test, Environmental Science \& Technology, 48 (2014) 2862-2869.

[14] Y.Q. Liu, G.V. Lowry, Effect of particle age ( $\mathrm{Fe}^{0}$ content) and solution $\mathrm{pH}$ on NZVI reactivity: $\mathrm{H}_{2}$ evolution and TCE dechlorination, Environmental Science \& Technology, 40 (2006) 6085-6090. 
[15] Y. Su, A.S. Adeleye, Y. Huang, X. Sun, C. Dai, X. Zhou, Y. Zhang, A.A. Keller, Simultaneous removal of cadmium and nitrate in aqueous media by nanoscale zerovalent iron (nZVI) and Au doped nZVI particles, Water Research, 63 (2014) 102-111.

[16] Z. Li, K. Greden, P.J. Alvarez, K.B. Gregory, G.V. Lowry, Adsorbed polymer and NOM limits adhesion and toxicity of nano scale zerovalent iron to E. coli, Environmental Science \& Technology, 44 (2010) 3462-3467.

[17] A.B.M. Giasuddin, S.R. Kanel, H. Choi, Adsorption of humic acid onto nanoscale zerovalent iron and its effect on arsenic removal, Environmental Science \& Technology, 41 (2007) 2022-2027.

[18] M. Velimirovic, L. Carniato, Q. Simons, G. Schoups, P. Seuntjens, L. Bastiaens, Corrosion rate estimations of microscale zerovalent iron particles via direct hydrogen production measurements, Journal of Hazardous Materials, 270 (2014) 18-26.

[19] T. Phenrat, N. Saleh, K. Sirk, H.J. Kim, R.D. Tilton, G.V. Lowry, Stabilization of aqueous nanoscale zerovalent iron dispersions by anionic polyelectrolytes: adsorbed anionic polyelectrolyte layer properties and their effect on aggregation and sedimentation, Journal of Nanoparticle Research, 10 (2008) 795-814.

[20] N. Saleh, H.-J. Kim, T. Phenrat, K. Matyjaszewski, R.D. Tilton, G.V. Lowry, Ionic strength and composition affect the mobility of surface-modified $\mathrm{Fe}^{0}$ nanoparticles in water-saturated sand columns, Environmental Science \& Technology, 42 (2008) 3349-3355.

[21] T.L. Johnson, M.M. Scherer, P.G. Tratnyek, Kinetics of halogenated organic compound degradation by iron metal, Environmental Science \& Technology, 30 (1996) 2634-2640.

[22] P.G. Tratnyek, T.L. Johnson, M.M. Scherer, G.R. Eykholt, Remediating ground water with zerovalent metals: Chemical considerations in barrier design, Ground Water Monit. Remediat., 17 (1997) 108-114.

[23] D.M. Cwiertny, A.L. Roberts, On the nonlinear relationship between $\mathrm{k}\left({ }_{\text {obs }}\right)$ and reductant mass loading in iron batch systems, Environmental Science \& Technology, 39 (2005) 8948-8957. 
[24] J. Gotpagar, E. Grulke, T. Tsang, D. Bhattacharyya, Reductive dehalogenation of trichloroethylene using zero-valent iron, Environ. Prog., 16 (1997) 137-143.

[25] S. Choe, Y.Y. Chang, K.Y. Hwang, J. Khim, Kinetics of reductive denitrification by nanoscale zero-valent iron, Chemosphere, 41 (2000) 1307-1311.

[26] J. Fan, Y. Guo, J. Wang, M. Fan, Rapid decolorization of azo dye methyl orange in aqueous solution by nanoscale zerovalent iron particles, Journal of Hazardous Materials, 166 (2009) 904-910.

[27] E.J. Weber, Iron-mediated reductive transformations: Investigation of reaction mechanism, Environmental Science \& Technology, 30 (1996) 716-719.

[28] W. Labaky, J.F. Devlin, R.W. Gillham, Probe for measuring groundwater velocity at the centimeter scale, Environmental Science \& Technology, 41 (2007) 8453-8458.

[29] E.L. Cussler, Diffusion: mass transfer in fluid systems Cambridge University Press, New York, 1988.

[30] Y. Liu, T. Phenrat, G.V. Lowry, Effect of TCE concentration and dissolved groundwater solutes on NUI-Promoted TCE dechlorination and $\mathrm{H}_{2}$ evolution, Environmental Science \& Technology, 41 (2007) 7881-7887.

[31] Y.Q. Liu, H. Choi, D. Dionysiou, G.V. Lowry, Trichloroethene hydrodechlorination in water by highly disordered monometallic nanoiron, Chem. Mat., 17 (2005) 5315-5322.

[32] J.T. Nurmi, P.G. Tratnyek, V. Sarathy, D.R. Baer, J.E. Amonette, K. Pecher, C.M. Wang, J.C. Linehan, D.W. Matson, R.L. Penn, M.D. Driessen, Characterization and properties of metallic iron nanoparticles: Spectroscopy, electrochemistry, and kinetics, Environmental Science \& Technology, 39 (2005) 1221-1230.

[33] H.-J. Kim, T. Phenrat, R.D. Tilton, G.V. Lowry, $\mathrm{Fe}^{0}$ Nanoparticles Remain Mobile in Porous Media after Aging Due to Slow Desorption of Polymeric Surface Modifiers, Environ. Sci. Technol, 43 (2009) 3824-3830. 
[34] R. Crane, H. Pullin, J. Macfarlane, M. Silion, I. Popescu, M. Andersen, V. Calen, T. Scott, Field Application of Iron and Iron-Nickel Nanoparticles for the Ex Situ Remediation of a Uranium-Bearing Mine Water Effluent, Journal of Environmental Engineering, 141 (2015) 04015011.

[35] T. Phenrat, N. Saleh, K. Sirk, R.D. Tilton, G.V. Lowry, Aggregation and sedimentation of aqueous nanoscale zerovalent iron dispersions, Environmental Science \& Technology, 41 (2007) 284-290.

[36] B.C. Reinsch, B. Forsberg, R.L. Penn, C.S. Kim, G.V. Lowry, Chemical Transformations during Aging of Zerovalent Iron Nanoparticles in the Presence of Common Groundwater Dissolved Constituents, Environmental Science \& Technology, 44 (2010) 3455-3461.

[37] E. Bi, I. Bowen, J. Devlin, Effect of Mixed Anions (HCO3-- SO42-- ClO4-) on Granular Iron (Fe0) Reactivity, Environmental Science \& Technology, 43 (2009) 5975-5981.

[38] A. Agrawal, W.J. Ferguson, B.O. Gardner, J.A. Christ, J.Z. Bandstra, P.G. Tratnyek, Effects of carbonate species on the kinetics of dechlorination of 1, 1, 1-trichloroethane by zero-valent iron, Environmental Science \& Technology, 36 (2002) 4326-4333.

[39] P.J. Vikesland, J. Klausen, H. Zimmermann, A.L. Roberts, W.P. Ball, Longevity of granular iron in groundwater treatment processes: changes in solute transport properties over time, J. Contam. Hydrol., 64 (2003) 3-33.

[40] C. Gibbs, Characterization and application of Ferrozine iron reagent as a ferrous iron indicator, Analytical Chemistry, 48 (1976) 1197.

[41] R.Y.S. Irene Man-Chi Lo, Keith C. K. Lai, Zero-valent iron reactive materials for hazardous waste and inorganics removal ASCE, 2007.

[42] Y.Q. Liu, S.A. Majetich, R.D. Tilton, D.S. Sholl, G.V. Lowry, TCE dechlorination rates, pathways, and efficiency of nanoscale iron particles with different properties, Environmental Science \& Technology, 39 (2005) 1338-1345.

[43] F.D. Kopinke, G. Speichert, K. Mackenzie, E. Hey-Hawkins, Reductive dechlorination in water: Interplay of sorption and reactivity, Appl. Catal. B: Environ., 181 (2016) 747-753. 
[44] J. Gao, W. Wang, A.J. Rondinone, F. He, L. Liang, Degradation of Trichloroethene with a Novel Ball Milled Fe-C Nanocomposite, Journal of Hazardous Materials, 300 (2015) 443-450.

[45] G.V. Lowry, M. Reinhard, Hydrodehalogenation of 1-to 3-carbon halogenated organic compounds in water using a palladium catalyst and hydrogen gas, Environmental Science \& Technology, 33 (1999) 1905-1910.

[46] C.G. Schreier, M. Reinhard, Catalytic hydrodehalogenation of chlorinated ethylenes using palladium and hydrogen for the treatment of contaminated water, Chemosphere, 31 (1995) 3475-3487. [47] H.-L. Lien, W.-x. Zhang, Nanoscale iron particles for complete reduction of chlorinated ethenes, Colloids and Surfaces A: Physicochemical and Engineering Aspects, 191 (2001) 97-105.

[48] F. Fagerlund, T. Illangasekare, T. Phenrat, H.J. Kim, G.V. Lowry, PCE dissolution and simultaneous dechlorination

by nanoscale zero-valent iron particles in a DNAPL source zone, J Contam Hydrol, 131 (2012) 9-28.

[49] F. He, D. Zhao, Manipulating the size and dispersibility of zerovalent iron nanoparticles by use of carboxymethyl cellulose stabilizers, Environmental Science \& Technology, 41 (2007) 6216-6221.

[50] F. He, D. Zhao, J. Liu, C.B. Roberts, Stabilization of Fe-Pd nanoparticles with sodium carboxymethyl cellulose for enhanced transport and dechlorination of trichloroethylene in soil and groundwater, Industrial \& Engineering Chemistry Research, 46 (2007) 29-34.

[51] N. Sakulchaicharoen, D.M. O'Carroll, J.E. Herrera, Enhanced stability and dechlorination activity of pre-synthesis stabilized nanoscale FePd particles, J. Contam. Hydrol., 118 (2010) 117-127.

[52] W.A. Arnold, A.L. Roberts, Pathways and kinetics of chlorinated ethylene and chlorinated acetylene reaction with $\mathrm{Fe}(\mathrm{O})$ particles, Environmental Science \& Technology, 34 (2000) 1794-1805.

[53] J. Wang, J. Farrell, Investigating the role of atomic hydrogen on chloroethene reactions with iron using tafel analysis and electrochemical impedance spectroscopy, Environmental Science \& Technology, 37 (2003) 3891-3896. 
[54] H. Song, E.R. Carraway, Reduction of chlorinated ethanes by nanosized zero-valent iron: Kinetics, pathways, and effects of reaction conditions, Environmental Science \& Technology, 39 (2005) 62376245.

[55] H. Song, E.R. Carraway, Reduction of chlorinated methanes by nano-sized zero-valent iron. Kinetics, pathways, and effect of reaction conditions, Environmental Engineering Science, 23 (2006) 272-284.

[56] J. Dolfing, M. Van Eekert, A. Seech, J. Vogan, J. Mueller, In situ chemical reduction (ISCR) technologies: Significance of low $\mathrm{E}_{\mathrm{h}}$ reactions, Soil \& Sediment Contamination, 17 (2008) 63-74.

[57] E. Silvester, L. Charlet, C. Tournassat, A. Gehin, J.M. Greneche, E. Liger, Redox potential measurements and Mossbauer spectrometry of Fe-II adsorbed onto Fe-III (oxyhydr)oxides, Geochim. Cosmochim. Acta, 69 (2005) 4801-4815.

[58] J.E. Amonette, D.J. Workman, D.W. Kennedy, J.S. Fruchter, Y.A. Gorby, Dechlorination of carbon tetrachloride by $\mathrm{Fe}(\mathrm{II})$ associated with goethite, Environmental Science \& Technology, 34 (2000) 4606-4613.

[59] E.C. Butler, K.F. Hayes, Effects of solution composition and $\mathrm{pH}$ on the reductive dechlorination of hexachloroethane by iron sulfide, Environmental Science \& Technology, 32 (1998) 1276-1284.

[60] E.C. Butler, K.F. Hayes, Factors influencing rates and products in the transformation of trichloroethylene by iron sulfide and iron metal, Environmental Science \& Technology, 35 (2001) 3884-3891.

[61] L. Charlet, E. Silvester, E. Liger, N-compound reduction and actinide immobilisation in surficial fluids by $\mathrm{Fe}(\mathrm{II})$ : the surface $\mathrm{Fe}(\mathrm{III}) \mathrm{OFe}(\mathrm{II}) \mathrm{OH}$ degrees species, as major reductant, Chemical Geology, 151 (1998) 85-93.

[62] K.M. Danielsen, K.F. Hayes, pH dependence of carbon tetrachloride reductive dechlorination by magnetite, Environmental Science \& Technology, 38 (2004) 4745-4752. 
[63] M. Elsner, R.P. Schwarzenbach, S.B. Haderlein, Reactivity of Fe(II)-bearing minerals toward reductive transformation of organic contaminants, Environmental Science \& Technology, 38 (2004) $799-807$.

[64] I. Hwang, B. Batchelor, Reductive dechlorination of tetrachloroethylene by Fe(II) in cement slurries, Environmental Science \& Technology, 34 (2000) 5017-5022.

[65] J. Klausen, S.P. Trober, S.B. Haderlein, R.P. Schwarzenbach, Reduction of substituted nitrobenzenes by $\mathrm{Fe}(\mathrm{II})$ in aqueous mineral suspensions, Environmental Science \& Technology, 29 (1995) 2396-2404.

[66] S. Ko, B. Batchelor, Identification of active agents for tetrachloroethylene degradation in Portland cement slurry containing ferrous iron, Environmental Science \& Technology, 41 (2007) 5824-5832.

[67] W. Lee, B. Batchelor, Abiotic, reductive dechlorination of chlorinated ethylenes by iron-bearing soil minerals. 2. Green rust, Environmental Science \& Technology, 36 (2002) 5348-5354.

[68] K. Pecher, S.B. Haderlein, R.P. Schwarzenbach, Reduction of polyhalogenated methanes by surface-bound Fe(II) in aqueous suspensions of iron oxides, Environmental Science \& Technology, 36 (2002) 1734-1741.

[69] G. Pon, M.R. Hyman, L. Semprini, Acetylene inhibition of trichloroethene and vinyl chloride reductive dechlorination, Environmental Science \& Technology, 37 (2003) 3181-3188.

[70] E. Bi, J.F. Devlin, B. Huang, Effects of mixing granular iron with sand on the kinetics of trichloroethylene reduction, Groundwater Monitoring and Remediation, 29 (2009) 56-62.

[71] R. Firdous, J.F. Devlin, Visualizations and Optimization of Iron-Sand Mixtures for Permeable Reactive Barriers, Groundwater Monitoring and Remediation, 35 (2015) 78-84.

[72] R.L. Johnson, J.T. Nurmi, G.S. O’Brien Johnson, D. Fan, R.L. O’Brien Johnson, Z. Shi, A.J. Salter-Blanc, P.G. Tratnyek, G.V. Lowry, Field-Scale Transport and Transformation of Carboxymethylcellulose-Stabilized Nano Zero-Valent Iron, Environmental Science \& Technology, 47 (2013) 1573-1580. 
[73] T. Kohn, K.J.T. Livi, A.L. Roberts, P.J. Vikesland, Longevity of granular iron in groundwater treatment processes: Corrosion product development, Environmental Science \& Technology, 39 (2005) 2867-2879.

[74] N.L. Garven, J.F. Devlin, Minimizing mass transfer effects in granular iron batch tests using GEM reactors, Journal of Environmental Engineering, 132 (2006) 1673-1676.

[75] G.R. Eykholt, C.R. Elder, C.H. Benson, Effects of aquifer heterogeneity and reaction mechanism uncertainty on a reactive barrier, Journal of Hazardous Materials, 68 (1999) 73-96.

[76] F. He, D. Zhao, C. Paul, Field assessment of carboxymethyl cellulose stabilized iron nanoparticles for in situ destruction of chlorinated solvents in source zones, Water Research, 44 (2010) 2360-2370.

[77] R. Seshadri, L. Adrian, D.E. Fouts, J.A. Eisen, A.M. Phillippy, B.A. Methe, N.L. Ward, W.C. Nelson, R.T. Deboy, H.M. Khouri, Genome sequence of the PCE-dechlorinating bacterium Dehalococcoides ethenogenes, Science, 307 (2005) 105-108.

[78] R.C. Daprato, F.E. Löffler, J.B. Hughes, Comparative analysis of three tetrachloroethene to ethene halorespiring consortia suggests functional redundancy, Environmental Science \& Technology, 41 (2007) 2261-2269.

[79] C. Audí-Miró, S. Cretnik, C. Torrentó, M. Rosell, O. Shouakar-Stash, N. Otero, J. Palau, M. Elsner, A. Soler, C, $\mathrm{Cl}$ and $\mathrm{H}$ compound-specific isotope analysis to assess natural versus $\mathrm{Fe}(0)$ barrier-induced degradation of chlorinated ethenes at a contaminated site, Journal of Hazardous Materials, 299 (2015) 747-754.

[80] B.M. Patterson, M. Lee, T.P. Bastow, J.T. Wilson, M.J. Donn, A. Furness, B. Goodwin, M. Manefield, Concentration effects on biotic and abiotic processes in the removal of 1, 1, 2trichloroethane and vinyl chloride using carbon-amended ZVI, J. Contam. Hydrol., 188 (2016) 1-11. 
Figures and Tables

(a)

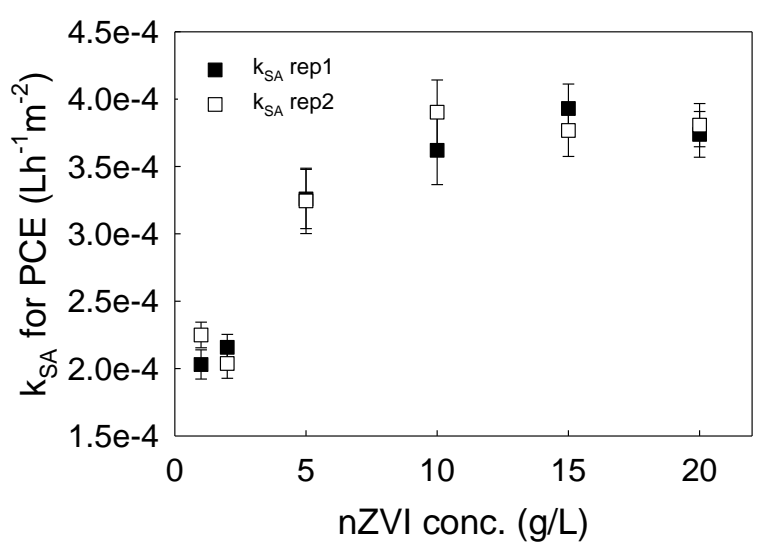

(c)

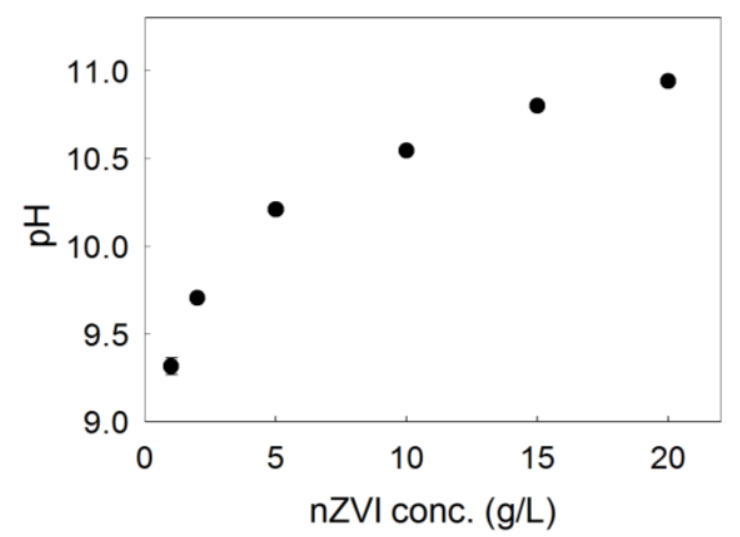

(b)

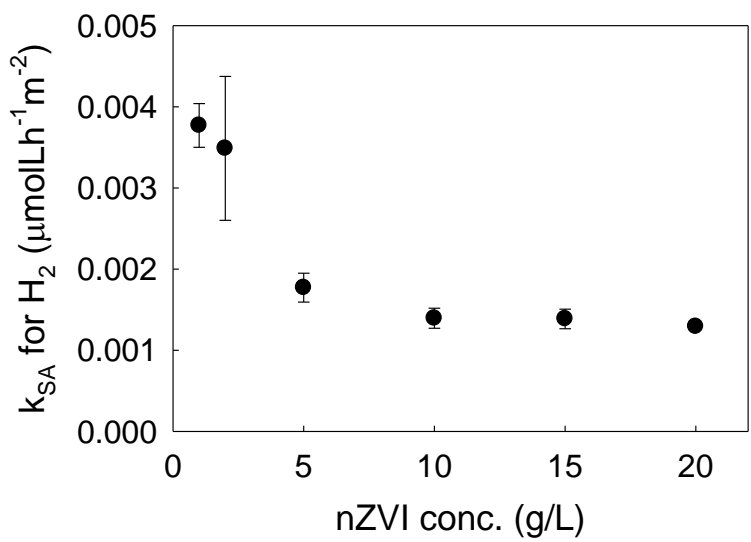

(d)

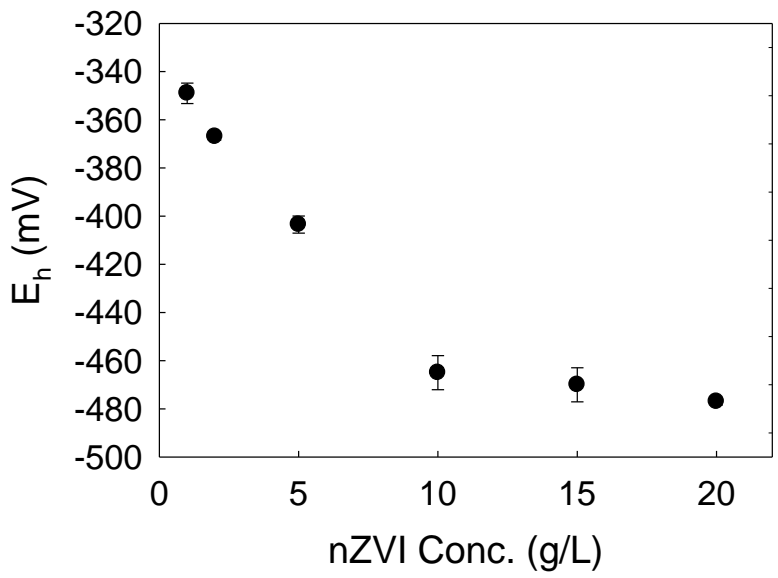

FIGURE 1. (a) $\mathrm{k}_{\mathrm{SA}}$ for PCE vs nZVI concentration $(1,2,5,10,15$ and $20 \mathrm{~g} / \mathrm{L}) . \square$ and represent the rate constants derived from the model fit for duplicate experimental results and error are $95 \%$ confidence intervals. The $\mathrm{Fe}^{0}$ content of $\mathrm{nZVI}$ was $47 \%$ when the reactivity was tested. (b) $\mathrm{k}_{\mathrm{SA}}$ for $\mathrm{H}_{2}$ vs nZVI concentration $(1,2,5,10,15$ and $20 \mathrm{~g} / \mathrm{L}$ ). (c) The final pH measured after the reaction. (d) The standard potential measured after the reaction. 


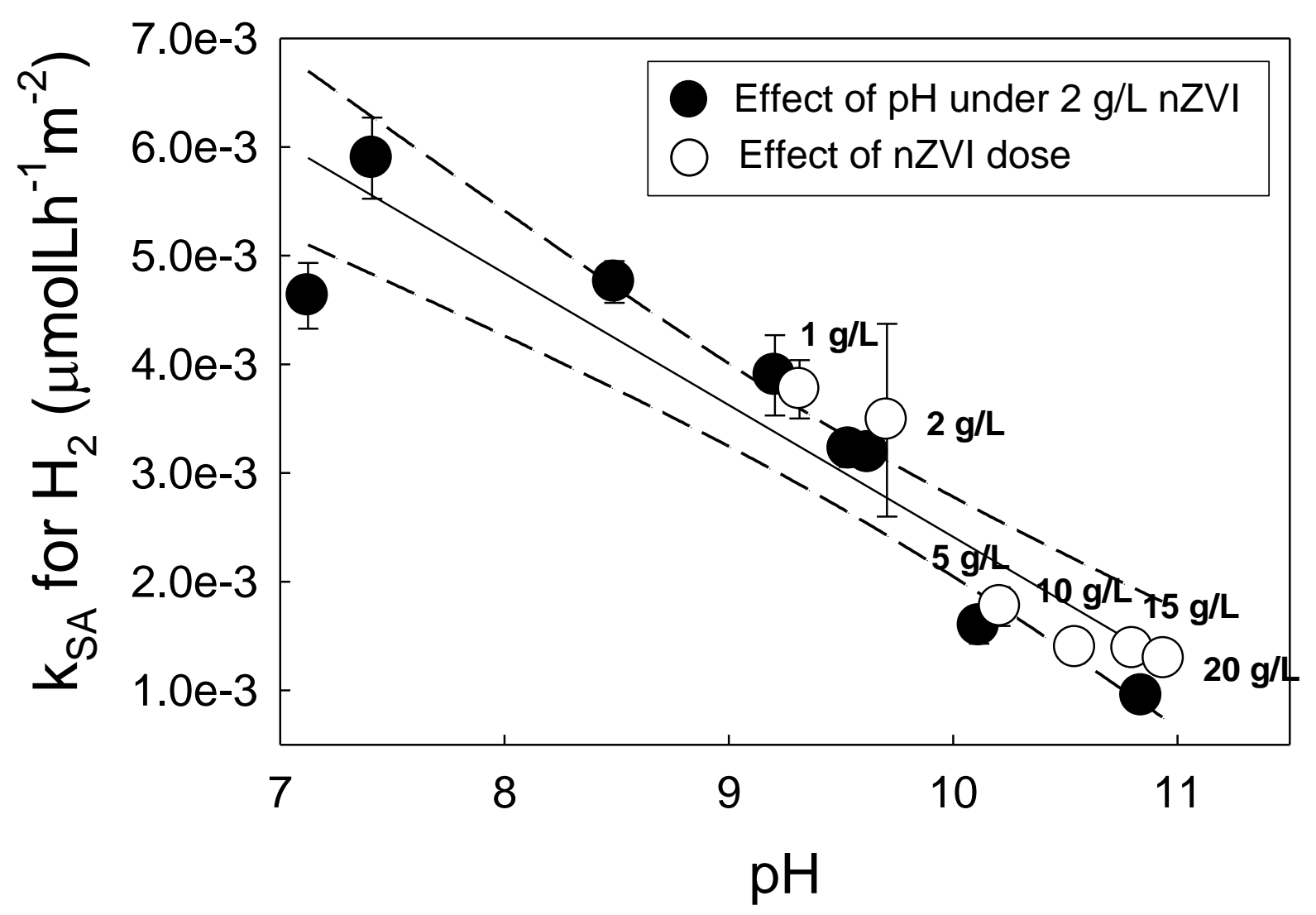

FIGURE 2. $\mathrm{k}_{\mathrm{SA}}$ for $\mathrm{H}_{2}$ with different $\mathrm{nZVI}$ mass loading $(1,2,5,10,15$ and $20 \mathrm{~g} / \mathrm{L})$ using $\mathrm{nZVI}$ with $47 \% \mathrm{Fe}^{0}$ content in $5 \mathrm{mM}$ sodium bicarbonate without adjusting $\mathrm{pH}(\mathrm{O})$ and with constant mass loading $(2 \mathrm{~g} / \mathrm{L})$ using $\mathrm{nZVI}$ with $36 \% \mathrm{Fe}^{0}$ content at different $\mathrm{pH}(\mathrm{O})$. Line is a linear fit of the data. Dashed lines are the $95 \%$ confidence intervals for that fit. 


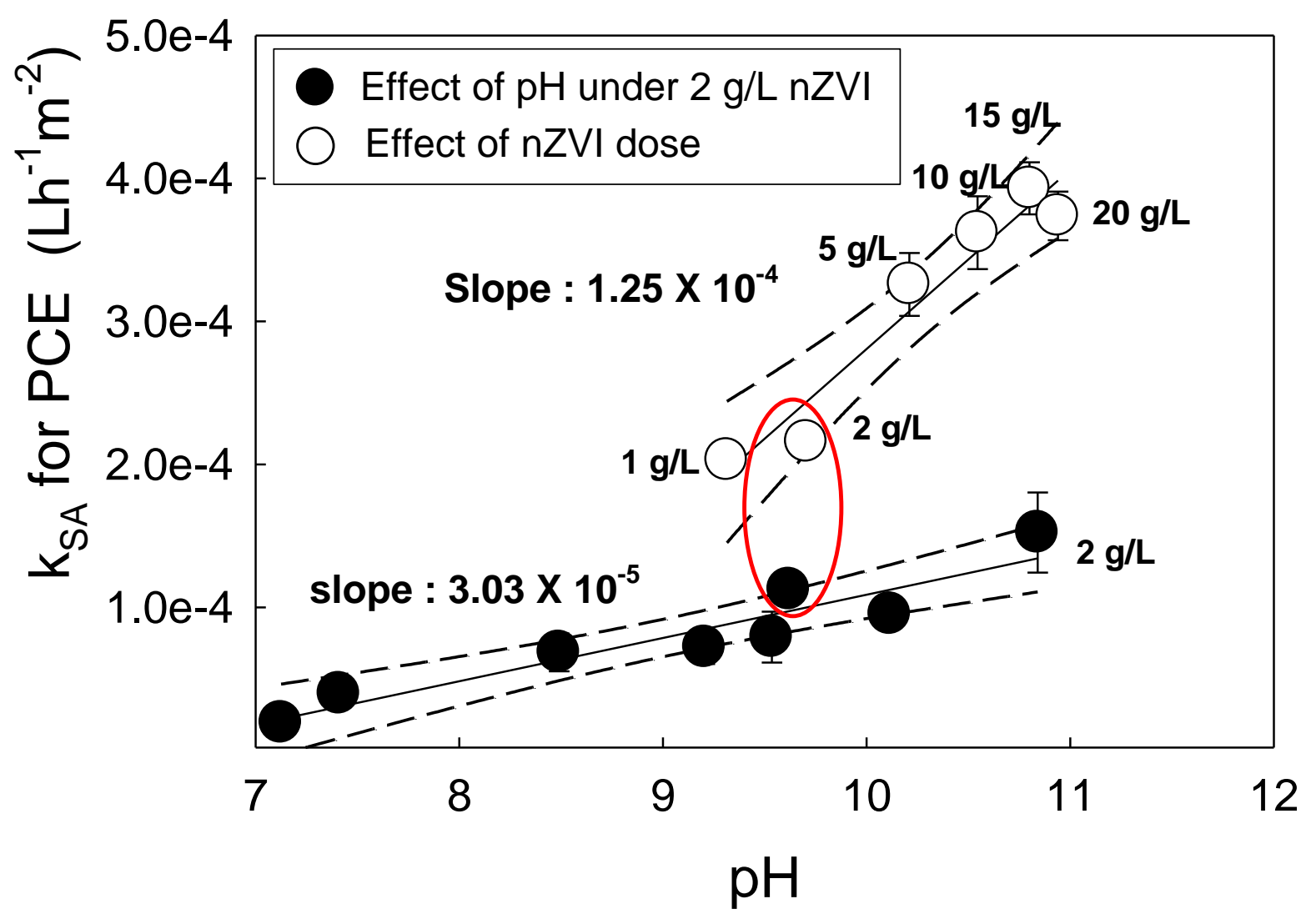

FIGURE 3. $\mathrm{k}_{\mathrm{SA}}$ for PCE with various $\mathrm{nZVI}$ mass loading $(1,2,5,10,15$ and $20 \mathrm{~g} / \mathrm{L})$ using $\mathrm{nZVI}$ with $47 \% \mathrm{Fe}^{0}$ content in $5 \mathrm{mM}$ sodium bicarbonate without adjusting $\mathrm{pH}(\mathrm{O})$ and with constant mass loading $(2 \mathrm{~g} / \mathrm{L})$ using $\mathrm{nZVI}$ with $36 \% \mathrm{Fe}^{0}$ content of at different $\mathrm{pH}(\mathrm{O})$. Line is linear fit of the data. Dashed lines are the $95 \%$ confidence interval for those fits. 


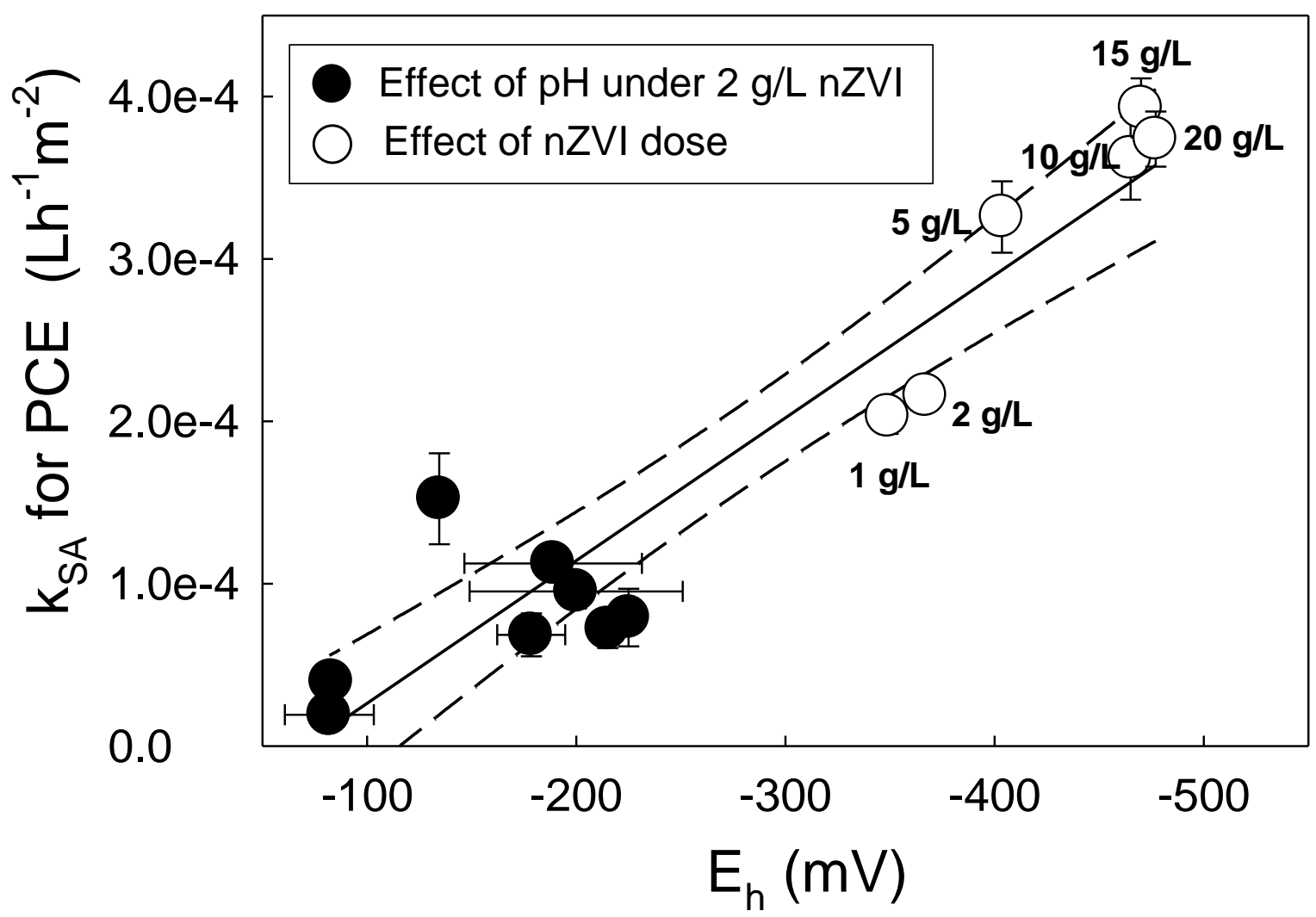

FIGURE 4. $\mathrm{k}_{\mathrm{SA}}$ for $\mathrm{E}_{\mathrm{h}}$ with various $\mathrm{nZVI}$ mass loading $(1,2,5,10,15$ and $20 \mathrm{~g} / \mathrm{L})$ using $\mathrm{nZVI}$ with $47 \% \mathrm{Fe}^{0}$ content in $5 \mathrm{mM}$ sodium bicarbonate without adjusting $\mathrm{pH}(\mathrm{O})$ and with constant mass loading ( $2 \mathrm{~g} / \mathrm{L})$ using $\mathrm{nZVI}$ with $36 \% \mathrm{Fe}^{0}$ content of at different $\mathrm{pH}(\bigcirc)$. Line is a linear fit of the data. Dashed lines are the $95 \%$ confidence interval for those fits. 


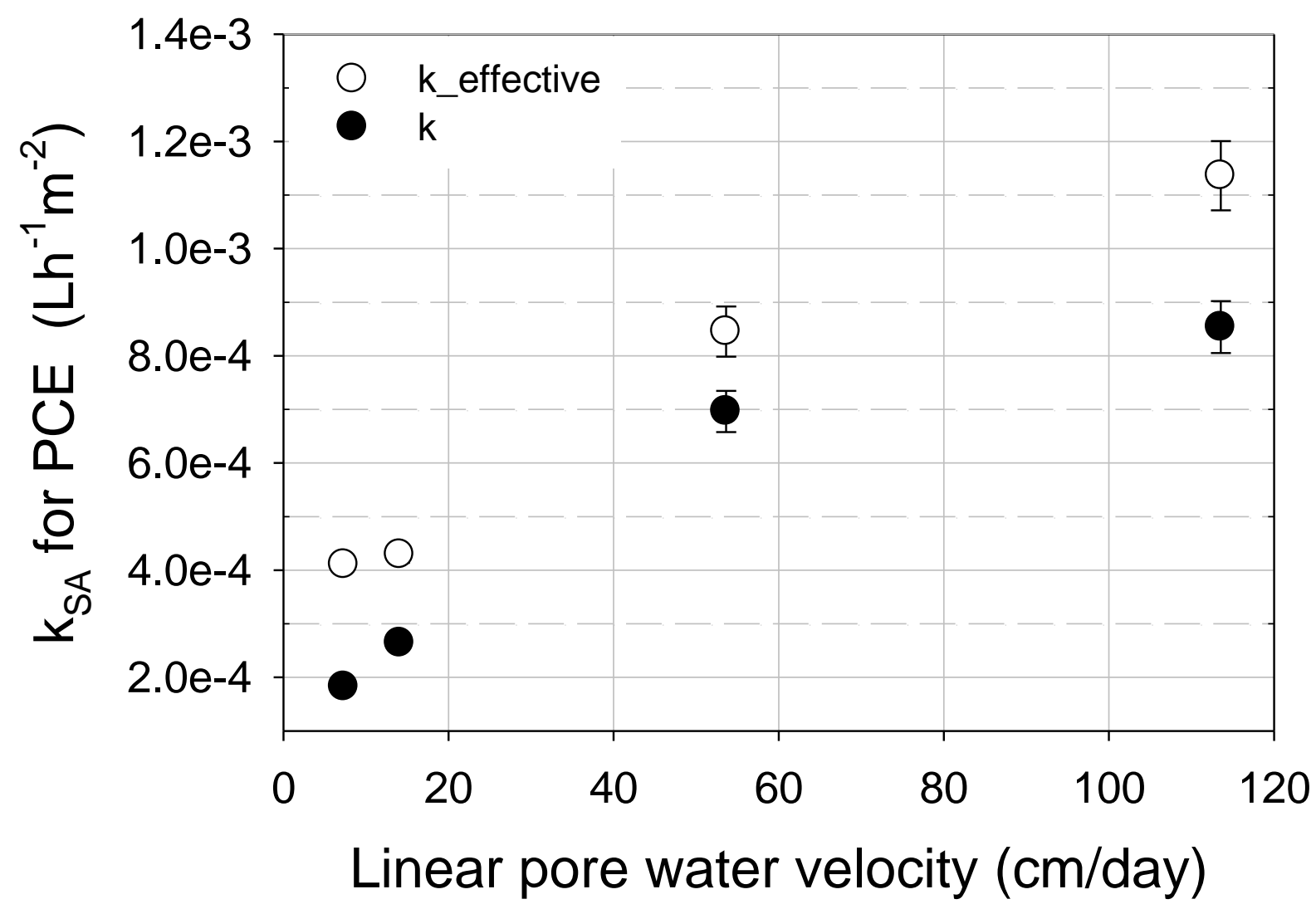

FIGURE 5. The influence of linear seepage velocity on $\mathrm{k}_{\mathrm{SA}}$ for PCE in the sand packed column with $10 \mathrm{~g} / \mathrm{L}$ of $\mathrm{nZVI}$. $\mathrm{k}$ _effective is the PCE dechlorination rate for the effective reactive zone (by considering only the non-oxidized zone as an effective length) and $\mathrm{k}$ is the PCE dechlorination rate calculated based on the assumption that nZVI along the total length of column remains reactive despite the color change to orange. 


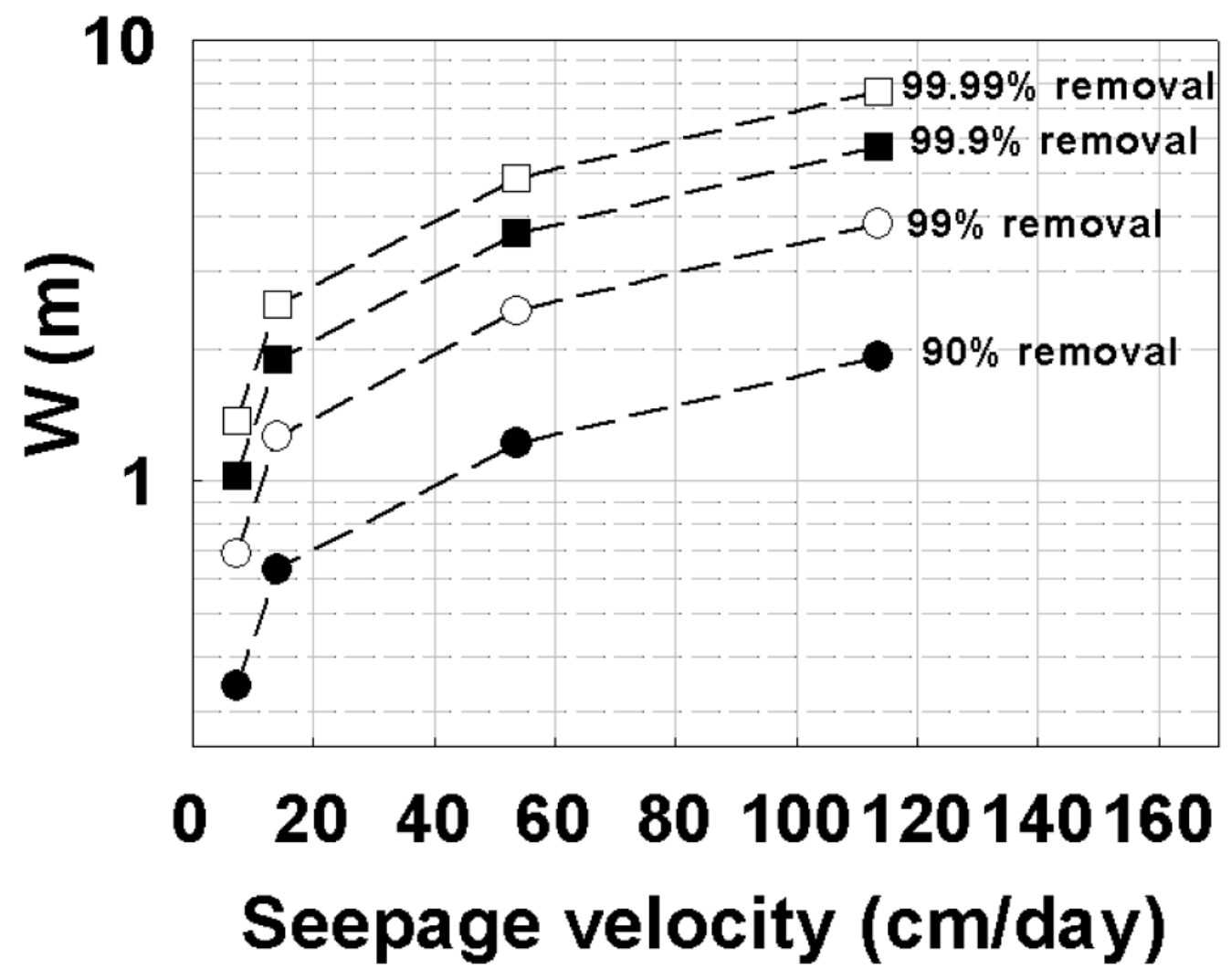

FIGURE 6. nZVI barrier width design curves as a function of seepage velocity to achieve selected target PCE removal efficiencies (90 \% removal (closed circle $(\bullet)), 99 \%$ removal (open circle $(O)), 99.9 \%$ removal (closed rectangle $(\square)$ ) and $99.99 \%$ removal (open rectangle ( $\square$ )). Curves are based on PCE dechlorination rate constants determined from the column studies using $10 \mathrm{~g} / \mathrm{L}$ nZVI particle concentration and the design barrier width estimation method by Eykholt et al [75] assuming a safety factor of 3 . 


\section{Non-Linear Behavior of PCE Dechlorination Rate $\left(k_{S A}\right)$}

\section{PCE source area}

nZVI emplaced by injection well

Groundwater Velocity Increases $\Rightarrow k_{\text {SA }}$ Increases $n Z V I$ mass loading Increases $\Rightarrow k_{S A}$ Increases 